\title{
Effect of insertion angle on the stability of orthodontic mini-implants in a rabbit tibia model: A finite element analysis
}

\author{
Efecto del ángulo de inserción en la estabilidad de miniimplantes ortodóncicos en un \\ modelo de tibia de conejo: Modelo de elementos finitos
}

\begin{abstract}
Víctor M. Araujo-Monsalvo', Mercy G. González-Aréas², Elisa Martínez-Coria³, Enrique Flores-Cuamatzi', Benjamín Araujo-Monsalvo ${ }^{4}$ and Víctor M. Domínguez-Hernández ${ }^{*}$

'Laboratorio de Biomecánica, Instituto Nacional de Rehabilitación Luis Guillermo Ibarra Ibarra, Mexico City, Mexico; ${ }^{2}$ Maestría en Ortodoncia, Universidad Intercontinental, Mexico City, Mexico; ${ }^{3}$ Servicio de Tomografía Computada, Instituto Nacional de Rehabilitación Luis Guillermo Ibarra Ibarra, Mexico City, Mexico; ${ }^{4}$ Departamento de Ingeniería de Sistemas, Sección de Estudios de Posgrado e Investigación, Escuela Superior de Ingeniería Mecánica y Eléctrica, Instituto Politécnico Nacional, Ciudad de México, México City, Mexico
\end{abstract}

\begin{abstract}
Introduction: Mini-implants are an alternative to traditional methods of anchorage in orthodontic treatment. However, there are still questions concerning their application, in particular, with the insertion angle. Objective: To determine whether the angle of insertion of the mini-implant is a determining factor in their primary stability when they support orthodontic loads. Materials and Methods: A finite element model (FEM) of tibia bone, spring and mini-implant was developed. The three-dimensional model of the rabbit tibia was constructed based on tomographic slices. The angles that were analyzed were $90^{\circ}, 80^{\circ}, 70^{\circ}, 60^{\circ}, 50^{\circ}, 45^{\circ}, 40^{\circ}$, and $30^{\circ}$. A horizontal force of $2 \mathrm{~N}$ applied to the head of the mini-implants was simulated. The von Mises stresses and displacements were determined using FEM. Results: Von Mises stresses were lower for an insertion angle of $40^{\circ}$ followed by $90^{\circ}$ and $70^{\circ}$; likewise, the displacements of the mini-implants with respect to the spring were lower for the $40^{\circ}$ angle followed by $90^{\circ}$ and $70^{\circ}$, we found a statistically significant association between the insertion angle and displacement. Conclusion: All mini-implants underwent a degree of angulation and displacement; however, mini-implants inserted to the bone surface at $40^{\circ}$ tend to have better primary stability, and they can withstand loads immediately.
\end{abstract}

KEY WORDS: Mini-implants. Orthodontics. Insertion angle. Finite element analysis. Biomechanics.

\section{Resumen}

Introducción: Los miniimplantes son una alternativa para los métodos de anclaje tradicionales en el tratamiento de ortodoncia. Sin embargo, existen interrogantes referentes a su uso, en particular en cuanto al ángulo de inserción. Objetivo: Determinar si el ángulo de inserción es un factor determinante en la estabilidad primaria de los miniimplantes cuando soportan cargas. Método: Se desarrolló un modelo tridimensional de elementos finitos del conjunto tibia, miniimplante y resorte a partir de cortes tomográficos; finalmente, el resorte fue modelado empleando elementos de contacto. Las angulaciones analizadas fueron $90^{\circ}, 80^{\circ}, 70^{\circ}, 60^{\circ}, 50^{\circ}, 45^{\circ}, 40^{\circ}$ y $30^{\circ}$. Una fuerza de $2 \mathrm{~N}$ fue aplicada a los implantes. Se determinaron los esfuerzos de von Mises y los desplazamientos empleando elementos finitos. Resultados: Los esfuerzos de von Mises fueron menores para un ángulo de inserción de $40^{\circ}$, seguido por los de $90^{\circ}$ y $70^{\circ}$; de igual forma, los desplazamientos en los miniimplantes con respecto al resorte fueron menores para un ángulo de $40^{\circ}$, seguido por los de $90^{\circ}$

\footnotetext{
Correspondence:

*Víctor Manuel Domínguez-Hernández

Calz. México-Xochimilco, 289

Col. Arenal de Guadalupe, Del. Tlalpan

Date of reception: 06-05-2018

Date of acceptance: 09-05-2018

C.P. 14389, Ciudad de México México City, Mexico

E-mail: vm_dominguez@yahoo.com.mx

DOI: 10.24875/CIRU.18000437
}

Cir Cir. 2019;87:190-195

Contents available at PubMed www.cirugiaycirujanos.com 
y $70^{\circ}$. Conclusión: Todos los minimplantes presentaron un cierto grado de angulación y desplazamiento, pero los insertados en la superficie ósea a $40^{\circ}$ tienden a presentar mejor estabilidad primaria y pueden ser inmediatamente sometidos a carga.

PALABRAS CLAVE: Miniimplantes. Ortodoncia. Ángulo de inserción. Método del elemento finito. Biomecánica.

\section{Introduction}

The first attempt to use an implant for orthodontic anchorage was reported in 1945 when it was proposed that metal implants may act like anchors ${ }^{1,2}$. However, it was not until 1983 that mini-implants were introduced into the orthodontic clinic to provide anchorage ${ }^{3-5}$. The use of mini-implants for absolute anchorage eliminates secondary movement, and their use has opened a new era in the biomechanics of orthodontics because they can provide anchorage without touching the back teeth. Meanwhile, they allow movement in the anterior teeth. Once their function ends, they can be removed .

The successful use of mini-implants for orthodontic treatment depends on several factors such as the shape of the mini-implant, its length, and the insertion site, among others. Mini-implants are an alternative to traditional methods of anchorage in orthodontic treatment due to their versatility ${ }^{7}$, minimal surgical invasion, and low cost ${ }^{8,9}$.

The insertion zone of mini-implants frequently used in clinical practice is the alveolar crest; however, root injury is a risk ${ }^{10-12}$. To avoid root damage and ensure good stability of mini-implants, some authors have proposed insertion angles between 30 and $45^{\circ 13-16}$. Other authors suggest insertion angles between 60 and $70^{\circ 17}$ because there is more space available near the apical region, while others favor placement at $90^{\circ 13,18}$ because it reduces the stress concentration and increases the probability of mini-implant stabilization.

In addition to the angle of insertion, there are still questions regarding stability and mechanical stresses around mini-implants due to the limited availability of accurate measurements that can be obtained directly from patients. Therefore, there have been many investigations in odontology using laboratory animals such as dogs, monkeys, rabbits, sheep, miniature pigs, rats, cats, goats, and mice ${ }^{19}$. However, the use of rabbits for research in oral implantology is a good choice due to the similarity of their bone density and diaphyseal bone composition to humans as well as economic aspects of their purchase and management due to their size and short life ${ }^{20,21}$.
It is difficult to experimentally determine the stresses and displacements of the mini-implants at different insertion angles in an animal model through in situ measurement, in addition to the difficulty in controlling the parameters of the study and variations in the samples. In contrast, the finite element method is a good tool for determining the distribution of stresses and displacements in biomechanics; in our case, it can be applied to accurately determine the mechanical parameters of mini-implants. If properly used, this technique could provide reliable results to validate the results obtained by experimental studies, as there are unknown conditions imposed by the biological system that cannot be modeled ${ }^{18,22}$.

The objective of this study is to analyze a three-dimensional (3D) finite element model (FEM) of the rabbit tibia to provide an approximate solution for estimating the response of mini-implants placed at different angles of insertion under certain given boundary conditions and to determine whether the angle is a determining factor of stability immediately after a force is applied.

\section{Materials and Methods}

FEMs were developed for the following components: (1) rabbit tibia, (2) mini-implants, and (3) springs. The model of the rabbit tibia was developed from 140 tomographic slices of the left leg of a skeletally mature male, white New Zealand rabbit, $3.5 \mathrm{~kg}$ in weight, employing a multislice computed tomography (CT) scanner (GE Light Speed, General Electric Company, Fairfield, CT, USA). 64 slices were made every $0.63 \mathrm{~mm}$. Images were processed so that a cloud of points described the geometry of the cortical wall of the tibia and the intramedullary canal. The 3D FEM of the tibia was developed from the cloud of points. The tibia was constructed using version 11 Ansys software (Ansys Inc., Canonsburg, PA, USA) (Fig. 1). The mini-implants were modeled with SolidWorks software version 2007 (SolidWorks Corp., Concord, MA, USA) (Fig. 2) using spring contact elements.

The mini-implant was placed approximately $20 \mathrm{~mm}$ below the proximal epiphyses of the tibia bone. 


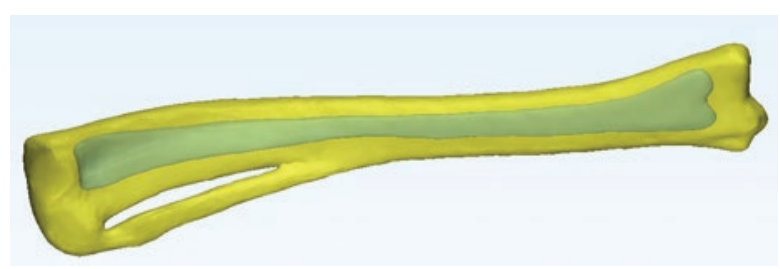

Figure 1. Three-dimensional reconstruction of a rabbit tibia.

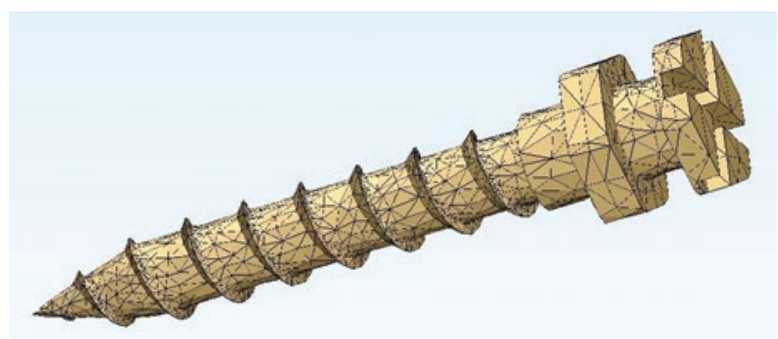

Figure 2. Finite element model of the mini-implant.

Placement was conducted through a single cortex (monocortical anchorage), varying the angle of insertion. A distal mini-implant was inserted $15 \mathrm{~mm}$ away from the first mini-implant to obtain an activation force of $2 \mathrm{~N}$. This mini-implant was considered an anchor, so it was placed at $90^{\circ}$ and inserted through both cortices of the tibia (bicortical anchoring).

All components were individually modeled and then assembled to create the finite element assembly of the tibia and mini-implant (Fig. 3). The springs were modeled with contact elements. We proposed eight case studies, in which the angle of the proximal mini-implant (6 $\mathrm{mm}$ long and $1.6 \mathrm{~mm}$ diameter) varied at $90^{\circ}, 80^{\circ}, 70^{\circ}, 60^{\circ}, 50^{\circ}, 45^{\circ}, 40^{\circ}$, and $30^{\circ}$, while the distal mini-implant ( $9 \mathrm{~mm}$ long and $1.6 \mathrm{~mm}$ diameter) was positioned at $90^{\circ}$ in all cases. The force used in the corresponding spring was $2 \mathrm{~N}(0.76 \mathrm{~mm}$ wire diameter, $10 \mathrm{~mm}$ long, and $5 \mathrm{~mm}$ length of activation). The entire assembly was exported for finite element analysis to ANSYS Workbench software (version 11.0; Ansys Inc., Canonsburg, PA, USA) (Fig. 4).

We considered three different materials: Cortical bone for the rabbit tibia, Ti-6Al-4V medical grade titanium alloy for the mini-implants, and 316L stainless steel for the springs.

The mechanical properties of the bone, mini-implants, and springs were taken from literature ${ }^{22-24}$. All materials in the model were considered homogeneous, isotropic, and linearly elastic. For the rabbit tibia, an elasticity modulus of $13.6 \mathrm{GPa}$ and Poisson's ratio of 1.3 were used. The mini-implants were modeled based on a Ti-6Al-4V titanium alloy with a modulus of the elasticity of $110 \mathrm{GPa}$ and a Poisson's ratio of

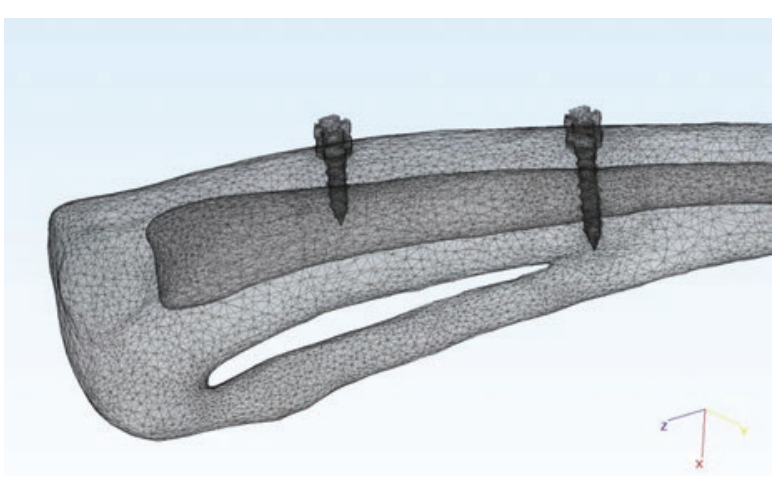

Figure 3. Finite element model assembly of tibia and mini-implants.

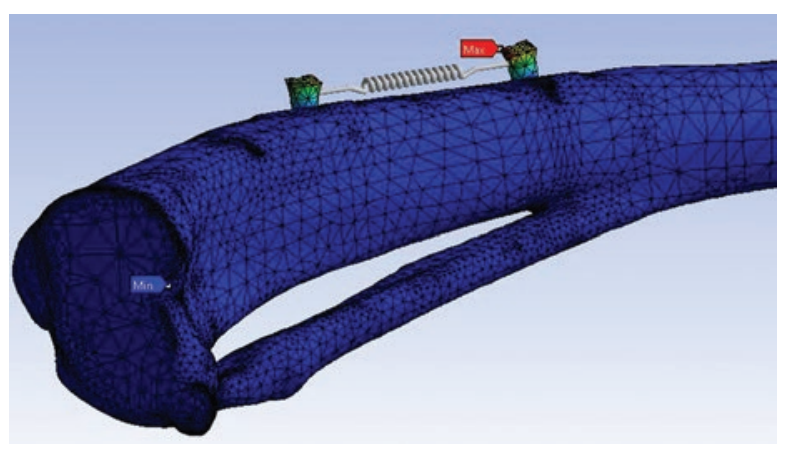

Figure 4. Von Mises stresses for tibia, mini-implants, and spring assembly.

0.3. The springs were modeled using $316 \mathrm{~L}$ stainless steel with an elastic modulus of $190 \mathrm{GPa}$ and a Poisson's ratio of 0.3 .

The model was restricted for movement in all directions in both epiphyses, and a tensile force of $2 \mathrm{~N}$ was applied to the center of the mini-implants through the spring. Then, the von Mises stresses and displacement were determined within the mini-implants and the surrounding bone.

\section{Results}

The case studies showed that lower stresses occurred in both surrounding bone holes and mini-implants at angles of $40^{\circ}, 90^{\circ}$, and $70^{\circ}$, indicating that the mini-implant at $40^{\circ}$ tended to reduce stress concentrations, which provided better stability under orthodontic loads followed by $90^{\circ}$ and $70^{\circ}$.

Von Mises stresses both in bone holes (area of bone drilled to insert the mini-implant) and in the different angles of mini-implants are shown in figure 5 . The first values, named $\mathrm{Bi} 90$, correspond to the mini-implant that was used as the anchor with bicortical insertion; the other values correspond to the mini-implants with monocortical insertion at insertion angles ranging from $90^{\circ}$ to $30^{\circ}$. 


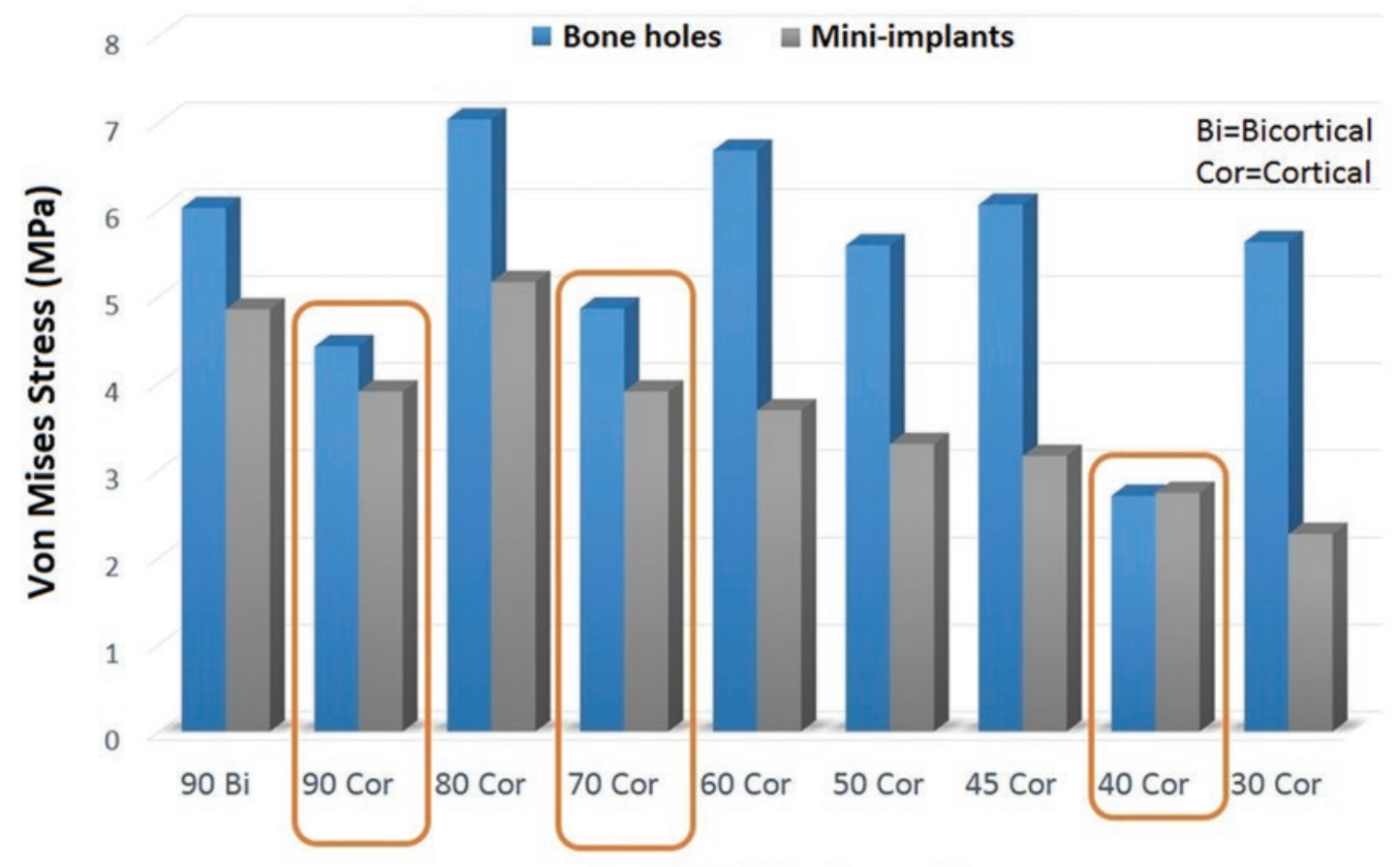

\section{Angle of mini-implants $\left({ }^{\circ}\right)$}

Figure 5. Maximum von Mises stress at bone holes and mini-implants. Lower stress values are marked.

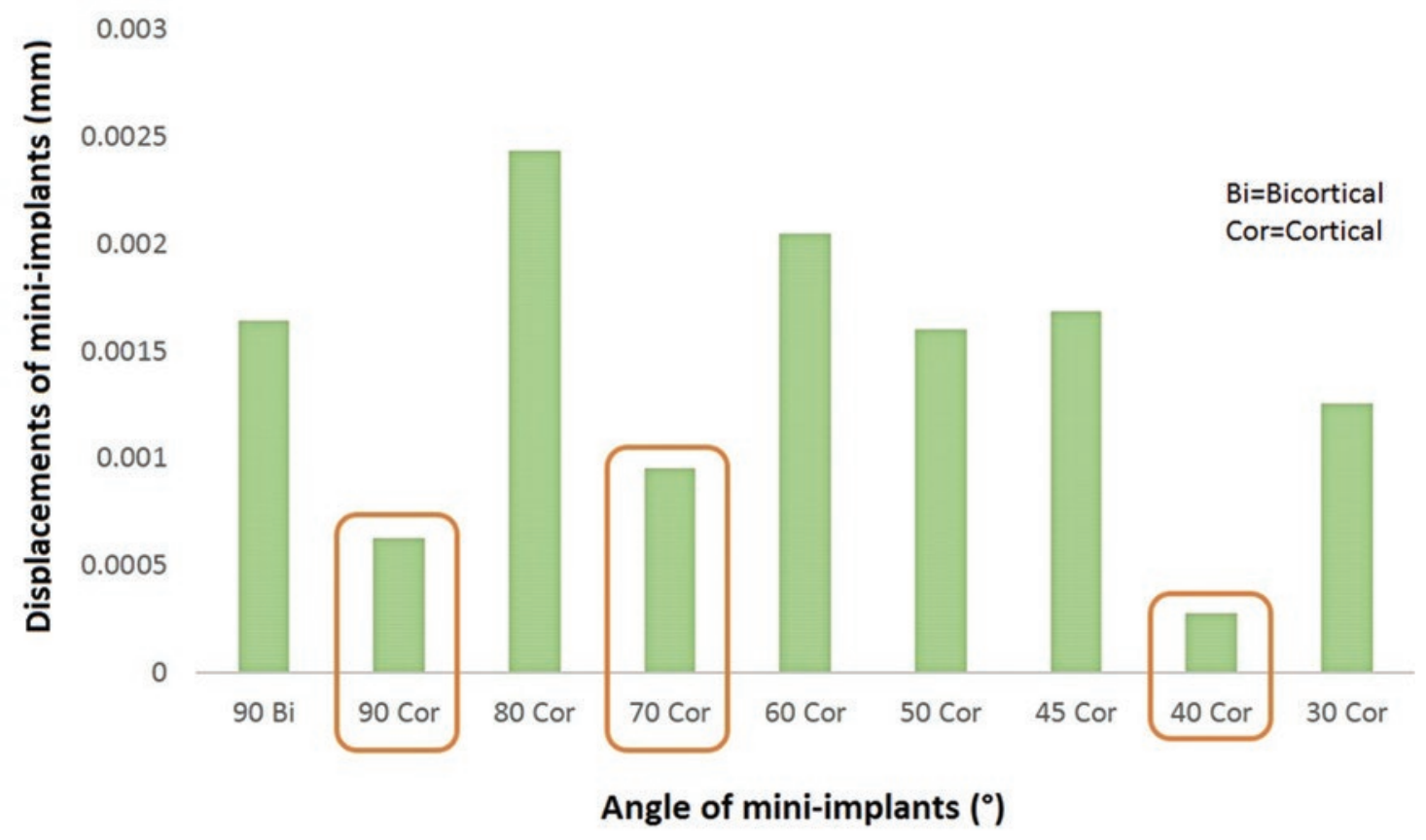

Figure 6. Displacements of mini-implants. Minor displacements are marked.

The movement of mini-implants with respect to the spring was less with oblique insertion at $40^{\circ}$ than with the mini-implants inserted at $90^{\circ}$ and $70^{\circ}$, indicating a slightly better stability that could be advantageous in regions with low bone quality (Fig. 6).

\section{Discussion}

The finite element method is a useful tool for the evaluation of the role of design parameters on the mechanical performance of mini-implants, as it allows 
us to analyze hypothetical scenarios that cannot be reproduced otherwise. In this paper, we studied the behavior of mini-implants at different insertion angles.

The results of the finite element analysis showed that all mini-implants suffered a different degree of angulation and displacement; however, mini-implants inserted at $40^{\circ}$ with respect to the bone surface tended to reduce stress concentrations and to exhibit less displacement, which increased the probability of providing better load stability for orthodontic forces.

Of the three insertion angles with better results, the angle that showed more displacement and higher stress levels was $70^{\circ}$ followed by $90^{\circ}$ and $40^{\circ}$; however, the mini-implant at $40^{\circ}$ showed lower levels in both variables.

There are still many questions about whether mini-implants remain stable throughout the entire orthodontic treatment ${ }^{25}$. A previous study showed that the mini-implants are stable during treatment ${ }^{26}$ and that they experience some degree of displacement when they are subjected to a load. Therefore, our study focused on evaluating the stability of mini-implants implanted at the different angles considered most common in clinical practice. One study recommended that for better insertion and stability, the mini-implants must be inserted between $60^{\circ}$ and $70^{\circ 17}$. Nevertheless, our research showed that the angle of $40^{\circ}$ was the most stable throughout the study followed by $90^{\circ}$ and $70^{\circ}$.

It is clear that the oblique insertion should be at $40^{\circ}$, as a larger insertion angle would increase bone contact; however, it is difficult to attach springs or other traction devices. Obliquely inserting the mini-implants decreases the possibility of creating a bicortical insertion, which Brettin et al. ${ }^{27}$ recommended for greater stability, according to their study comparing monocortical with bicortical anchorage.

The results of our study suggest that the $40^{\circ}$ oblique insertion provided slightly higher stability than the mini-implants placed at $90^{\circ}$, which can be advantageous in regions with low bone quality, although the bicortical anchor greatly increases stability and the mini-implant placed at $90^{\circ}$ ensures this stability.

Our study demonstrates the potential of the finite element method as an effective tool for the optimization of the stability of mini-implants and the minimization of risk when performing in vivo tests.

The validation of our results using finite element analysis by performing experimental research with an in vivo model (white, male New Zealand rabbits) using the mini-implants in the tibia with the best three angles of insertion found in this study $\left(40^{\circ}, 70^{\circ}\right.$, and $\left.90^{\circ}\right)$ is recommended.

\section{Acknowledgments}

The authors gratefully acknowledge the work done by technician Martín Luna Méndez from CT and UItrasound Department, at the Instituto Nacional de Rehabilitación Luis Guillermo Ibarra Ibarra.

\section{Conflicts of interest}

The authors declare no conflicts of interest related to the present manuscript.

\section{Funding}

There were no funding sources.

\section{Ethical disclosures}

Protection of human and animal subjects. The authors declare that the procedures followed were in accordance with the regulations of the relevant clinical research ethics committee and with those of the Code of Ethics of the World Medical Association (Declaration of Helsinki).

Confidentiality of data. The authors declare that no patient data appear in this article.

Right to privacy and informed consent. The authors declare that no patient data appear in this article.

\section{References}

1. Ritto AK. Micro implants in orthodontics. Int J Orthod Milwaukee. 2004; 15:22-4.

2. Melsen $B$. Is the intraoral-extradental anchorage changing the spectrum of orthodontics. In: McNamara JA, editor, Implants, Microimplants, Onplants and Transplants: New Answers to Old Questions in Orthodontics? Ann Arbor, MI, USA: The University of Michigan; 2005. p. 41-68.

3. Creekmore TD, Eklund MK. The possibility of skeletal anchorage. J Clin Orthod. 1983;17:266-9.

4. Block MS, Almerico B, Crawford C, Gardiner D, Chang A. Bone response to functioning implants in dog mandibular alveolar ridges augmented with distraction osteogenesis. Int J Oral Maxillofac Implants. 1998;13:342-51.

5. Labahauskaite B. Jankauskas G. Implants for orthodontic anchorage. Meta-analysis. Stomatologija. 2005;7:128-32.

6. Park HS, Kwon OW, Sung JH. Micro-implant anchorage for forced eruption of impacted canines. J Clin Orthod. 2004;38:297-302.

7. Ren Y. Mini-implants for direct or indirect orthodontic anchorage. Evid Based Dent. 2009;10:113.

8. Kanomi R. Mini-implant for orthodontic anchorage. J Clin Orthod. 1997; 31:763-7.

9. Costa A, Raffaini M, Melsen B. Miniscrews as orthodontic anchorage: A preliminary report. Int J Adult Orthodon Orthognath Surg. 1998;13:201-9.

10. Fabbroni G, Aabed S, Mizen K, Starr DG. Transalveolar screws and the incidence of dental damage: A prospective study. Int J Oral Maxillofac Surg. 2004;33:442-6. 
11. Asscherickx K, Vannet BV, Wehrbein $H$, Sabzevar MM. Root repair after injury from mini-screw. Clin Oral Implants Res. 2005;16:575-8.

12. Wilmes B, Su YY, Sadigh L, Drescher D. Predrilling force and insertion torques during orthodontic mini-implant insertion in relation to root contact. J Orofac Orthop. 2008;69:51-8.

13. Kyung HM, Park HS, Bae SM, Sung JH, Kim IB. Development of orthodontic micro-implants for intraoral anchorage. J Clin Orthod. 2003; 37:321-8.

14. Carano A, Velo S, Leone P, Siciliani G. Clinical applications of the miniscrew anchorage system. J Clin Orthod. 2005;39:9-24.

15. Lim JE, Lim WH, Chun YS. Quantitative evaluation of cortical bone thickness and root proximity at maxillary interradicular sites for orthodontic mini-implant placement. Clin Anat. 2008;21:486-91.

16. Noble J, Karaiskos NE, Hassard TH, Hechter FJ, Wiltshire WA. Stress on bone from placement and removal of orthodontic miniscrews at different angulations. J Clin Orthod. 2009;43:332-4.

17. Wilmes B, Su YY, Drescher D. Insertion angle impact on primary stability of orthodontic mini-implants. Angle Orthod. 2008;78:1065-70.

18. Jasmine MI, Yezdani AA, Tajir F, Venu RM. Analysis of stress in bone and microimplants during en-masse retraction of maxillary and mandibular anterior teeth with different insertion angulations: A 3-dimensional finite element analysis study. Am J Orthod Dentofacial Orthop. 2012;141:71-80.
19. Faggion CM Jr., Listl S, Giannakopoulos NN. The methodological quality of systematic rewiews of animal studies in dentistry. Vet J. 2012;192:140-7.

20. Mapara M, Thomas BS, Bhat KM. Rabbit as an animal model for experimental research. Dent Res J. 2012;9:111-8.

21. Stübinger $\mathrm{S}$, Dard $\mathrm{M}$. The rabbit as experimental model for research in implant dentistry and related tissue regeneration. J Invest Surg. 2013; 26:266-82.

22. Liu TC, Chang $\mathrm{CH}$, Wong TY, Liu JK. Finite element analysis of miniscrew implants used for orthodontic anchorage. Am J Orthod Dentofacial Orthop. 2012;141:468-76.

23. An YH. Mechanical properties of bone. In: An YH, Draughn RA, editors. Mechanical Testing of Bone and the Bone-Implant Interface. Boca Raton, FL, USA: CRC Press; 2000. p. 41-63.

24. Çifter M, Saraç M. Maxillary posterior intrusion mechanics with mini-implant anchorage evaluated with the finite element method. Am J Orthod Dentofacial Orthop. 2011;140:e233-41.

25. Wehrbein H, Göllner P. Skeletal anchorage in orthodontics - basics and clinical application. J Orofac Orthop. 2007:68:443-61.

26. El-Beialy AR, Abou-El-Ezz AM, Attia KH, El-Bialy AM, Mostafa YA. Loss of anchorage of miniscrews: A 3-dimensional assessment. Am J Orthod Dentofacial Orthop. 2009;136:700-7.

27. Brettin BT, Grosland NM, Qian F, et al. Bicortical vs monocortical orthodontic skeletal anchorage. Am J Orthod Dentofacial Orthop. 2008;134:625-35. 